\title{
KNOWLEDGE AND ATTITUDES TOWARD EPILEPSY AMONG PRIMARY, SECONDARY AND TERTIARY LEVEL TEACHERS
}

\author{
Fábio Galvão Dantas', Gibran Agra Cariri2, Gustavo Agra Cariri', \\ Antônio Roberto Vaz Ribeiro Filho
}

\begin{abstract}
The attitudes toward people with epilepsy are influenced by the degree of knowledge of the condition. Teachers usually do not receive any formal instruction on epilepsy during their training. This study was done to access three hundred teachers' knowledge and attitudes toward epilepsy by answering a questionnaire in order to quantify their knowledge, attitude and practice toward epilepsy. Almost all the teachers had heard about epilepsy yet could not demonstrate discrimination among the students. Some teachers still thought that epilepsy was contagious. A few others either objected to having epileptic children in their classes or did not think that an epileptic child could achieve higher studies. The knowledge about the clinical characteristics and initial procedures to attend a person during a seizure was unsatisfactory. We conclude that schools should offer some kind of knowledge or assistance in health services and physicians must ensure that these teachers have sufficient knowledge of epilepsy. Also general public education campaigns should be encouraged in this field.
\end{abstract}

KEY WORDS: epilepsy, attitude, prejudice, public awareness.

Atitude e percepção sobre epilepsia entre professores de primeiro, segundo e terceiro graus

\begin{abstract}
RESUMO - As atitudes referentes a pacientes com epilepsia são influenciadas pelo grau de conhecimento acerca desta patologia. Os professores geralmente não recebem instruções formais a este respeito. Este estudo procurou avaliar o grau de conhecimento e atitude quanto à epilepsia em trezentos professores, os quais responderam um questionário que quantifica o conhecimento, atitude e prática. Quase todos os professores já tinham ouvido falar sobre epilepsia e não discriminavam seus alunos. Alguns ainda acreditavam em contágio e poucos professores referiram objeções à presença de alunos com epilepsia em suas classes ou achavam que uma criança com epilepsia não poderia se tornar um bom professor. 0 conhecimento quanto às características clínicas ou procedimentos iniciais diante de uma crise epiléptica foi insatisfatório. Os resultados evidenciam que escolas médicas e médicos devem proporcionar um melhor conhecimento sobre epilepsia aos professores e campanhas educativas públicas devem também objetivar melhor esclarecimento sobre estas questões.
\end{abstract}

PALAVRAS-CHAVE: epilepsia, atitude, preconceito, percepção.

Epilepsy is one of the most common neurological diseases with a prevalence rate varying from 2.8 to 19.5 per 1,000 general population ${ }^{1-6}$ and it prevails more specially among school children. There are no epidemiological studies in our region related to the prevalence of epilepsy in school children. Empirically, the most frequent causes of symptomatic epilepsy are neurocysticercosis, birth brain injury, intracranial infections and cerebrovascular disease. The last three causes are the most prevalent in other report ${ }^{1}$. In Brazil, neurocysticercosis reflects an important sanitary problem related to the insufficiency of basic health educative programs. Epilepsy is just one of our public health problems and the frequent need for continuous medical care and antiepileptic drugs availability justify the careful planning of a social program related to this disease. Persons suffering from epilepsy are often stigmatized mainly as a result of fear of the unexpected and public loss of self-control. During a seizure, one may lose control of the body and return to a primitive form of behavior that may result in social rejection ${ }^{7}$. Sometimes the social discrimination against persons with epilepsy may be more devastating than the disease itself. Some children with epilepsy may be rejected from their classes because of frequent seizures and this makes some

Disciplina de Neurologia da Faculdade de Medicina da Universidade Federal da Paraíba - Campus II, Campina Grande PB, Brasil: ${ }^{1}$ Profes-

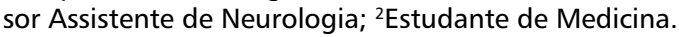

Received 12 March 2001, received in final form 29 May 2001. Accepted 6 June 2001. 
teachers uncomfortable with their presence in class ${ }^{8}$. Adults with epilepsy usually have problems with adaptation, institutionalization and access to public accommodations ${ }^{9}$. The disease may also cause the loss of employment and difficulties to marry. They may also be rejected from social convivence because there are people that still believe that the disease may be transmissible by contact with the patient's saliva. The essence of discrimination is forming opinions about others based not on individual merits but rather on being a member of a group that has certain assumed characteristics ${ }^{9}$. The attitudes toward people with epilepsy are influenced by the degree of knowledge of the condition ${ }^{9}$. In general, teachers do not receive any formal instruction on epilepsy during their training despite the fact that as much as $40 \%$ of children's developing life is spent at school. During this time teachers could play an important part in the management and surveillance of children with epilepsy ${ }^{10}$.

This study was done to access the teachers' knowledge and attitude toward epilepsy.

\section{METHOD}

This study was done in the urban area in the northeast of Brazil in a city called Campina Grande (population 360,000 ) situated in a poor region whose economy is based on industry, commercial activities and services. The city is considered an educational regional pole as there are several public and private primary and secondary schools and two public Universities, which also attend students coming from other states. Three hundred teachers from 30 public and 8 private schools were invited to participate in the study by answering a questionnaire derived from a previous study ${ }^{11}$ which quantifies the knowledge, attitude and practice toward epilepsy among selected populations. We divided the teachers in 3 groups: group 1 with one hundred primary level teachers (middle school), group 2 with one hundred secondary level teachers (high school) and group 3 with one hundred tertiary level teachers (college). The schools were chosen at random but not in a systematic equiprobabilistic fashion.

The questions were mainly of the yes/no/don't know variety but also allowed teachers to express their opinions by means of free answers. For the question about the initial procedures in attending a person during a seizure we considered as main correct initial procedures: to protect and to turn the head to one side in order to permit the saliva flow; to keep ventilation on and to stay near the subject until the end of the seizure, avoiding any harmful situations. We considered as less important correct initial procedures acts like taking off clothes and removing nearby objects. Inadequate initial procedures were all the ones which may be harmful or helpless to the patient, like pulling the tongue or putting objects or water in his mouth.

We utilized the Chi-square test $\left(\chi^{2}\right)$ to verify the statistical significance of the three groups comparative results (questions 1 to 10). For the questions with two alternatives - yes/no (questions 1, 2, 3, 5 and 6) we considered statistically significant if $\chi^{2}>9.21$. For the questions with three alternatives - yes/no/l don't know (questions $4,7,8,9$ and $10)$, if $\chi^{2}>13.3$.

\section{RESULTS}

The data related to the schools, teachers' age, sex and graduation level are presented in Table 1. The responses to the questions 1 to 10 are summarized in Table 2 . The answers to the question 11 are provided in Table 3.

Table 1. Schools, teachers' age, sex and professional teaching graduation.

\begin{tabular}{lccc}
\hline & $\begin{array}{c}\text { Group 1 } \\
\text { 100 teachers (100\%) }\end{array}$ & $\begin{array}{c}\text { Group 2 } \\
100 \text { teachers (100\%) }\end{array}$ & $\begin{array}{c}\text { Group 3 } \\
\text { Public schools teachers }\end{array}$ \\
Private schools teachers & $66 \%$ & $27 \%$ & $83 \%$ \\
Teachers' age: & $34 \%$ & $73 \%$ & $17 \%$ \\
$0-29$ & & & \\
$30-49$ & $26 \%$ & $26 \%$ & $6 \%$ \\
$>49$ & $69 \%$ & $65 \%$ & $81 \%$ \\
Sex: & $5 \%$ & $9 \%$ & $13 \%$ \\
$\quad$ Male & & & $49 \%$ \\
Female & $11 \%$ & $40 \%$ & $51 \%$ \\
Graduation level: & $89 \%$ & $60 \%$ & \\
$\quad$ High school & & & $41 \%$ \\
$\quad$ College & $27 \%$ & $9 \%$ & $55 \%$ \\
$\quad$ Graduate school & $70 \%$ & $10 \%$ & \\
\hline
\end{tabular}


Table 2. Responses to questions about familiarity and attitudes toward epilepsy.

\begin{tabular}{lccccccccc}
\hline Questions/ $\chi^{2}$ & \multicolumn{3}{c}{ Group I } & \multicolumn{2}{c}{ GROUP II } & \multicolumn{2}{c}{ Group III } \\
& Yes & No & $\begin{array}{c}\text { I don't } \\
\text { know }\end{array}$ & Yes & No & $\begin{array}{r}\text { I don't } \\
\text { know }\end{array}$ & Yes & $\begin{array}{r}\text { No } \\
\text { I don't } \\
\text { know }\end{array}$ \\
\hline $1 / 2.0$ (NS) & $98 \%$ & $2 \%$ & - & $100 \%$ & - & - & $99 \%$ & $1 \%$ & - \\
$2 / 0.4$ (NS) & $88 \%$ & $12 \%$ & - & $87 \%$ & $13 \%$ & - & $85 \%$ & $15 \%$ & - \\
$3 / 0.7$ (NS) & $83 \%$ & $17 \%$ & - & $86 \%$ & $14 \%$ & - & $87 \%$ & $13 \%$ & - \\
$4 / 14.6$ (S) & $2 \%$ & $85 \%$ & $13 \%$ & $5 \%$ & $93 \%$ & $2 \%$ & - & $93 \%$ & $7 \%$ \\
$5 / 7.6$ (NS) & $88 \%$ & $12 \%$ & - & $96 \%$ & $4 \%$ & - & $84 \%$ & $16 \%$ & - \\
$6 / 6.8$ (NS) & $7 \%$ & $93 \%$ & - & $5 \%$ & $95 \%$ & - & - & $100 \%$ & - \\
$7 / 14.6$ (S) & $83 \%$ & $6 \%$ & $11 \%$ & $87 \%$ & - & $13 \%$ & $93 \%$ & $1 \%$ & $6 \%$ \\
$8 / 3.1$ (NS) & $85 \%$ & $4 \%$ & $11 \%$ & $86 \%$ & $3 \%$ & $11 \%$ & $91 \%$ & $4 \%$ & $5 \%$ \\
$9 / 7.0$ (NS) & $26 \%$ & $41 \%$ & $33 \%$ & $27 \%$ & $52 \%$ & $21 \%$ & $20 \%$ & $57 \%$ & $23 \%$ \\
$10 / 10.6$ (NS) & $32 \%$ & $46 \%$ & $22 \%$ & $43 \%$ & $35 \%$ & $22 \%$ & $54 \%$ & $32 \%$ & $14 \%$ \\
\hline
\end{tabular}

1. Have you ever read or heard something about epilepsy or seizures?

2. Do you know someone who has epilepsy?

3. Have you ever seen an epileptic seizure?

4. Do you think epilepsy is a contagious disease?

5. Do you think there is discrimination against people who have epilepsy?

6. Would you object to having a student with epilepsy in your class?

7. Do you think a student with epilepsy may be as intelligent as others?

8. Do you think a person with epilepsy may become a teacher?

9. Do you think all the seizures are characterized by convulsive tremors and loss of consciousness?

10. Do you know the initial procedures to attend a person during a seizure?

Table 3. Most frequent answers to question 11 ("what initial procedures would you follow to attend a person during a seizure?").

\begin{tabular}{lccc}
\hline Procedure & Group I & Group II & Group III \\
\hline To pull the tongue & $16.62 \%$ & $16.92 \%$ & $18.16 \%$ \\
To remove nearing objects & $18.62 \%$ & $9.87 \%$ & $9.08 \%$ \\
To protect the head & $9.31 \%$ & $12.69 \%$ & $11.35 \%$ \\
To keep ventilation on & $10.64 \%$ & $11.28 \%$ & $11.35 \%$ \\
To take to a hospital & $1.33 \%$ & $5.64 \%$ & $11.35 \%$ \\
To wait for the end of the seizure & $11.97 \%$ & $8.46 \%$ & $11.35 \%$ \\
To put an object between the teeth & $3.99 \%$ & $4.23 \%$ & $4.54 \%$ \\
To lay the subject down & $7.98 \%$ & $9.87 \%$ & $6.81 \%$ \\
To take objects out of the mouth & $6.65 \%$ & $4.23 \%$ & $0 \%$ \\
To take the shirt out & $3.99 \%$ & $4.23 \%$ & $0 \%$ \\
To ensure post-ictal tranquility & $1.33 \%$ & $5.64 \%$ & $2.27 \%$ \\
To clean up the mouth permitting saliva flow & $3.99 \%$ & $5.64 \%$ & $4.54 \%$ \\
Other procedures & $1.33 \%$ & $1.41 \%$ & $9.08 \%$ \\
\hline
\end{tabular}

Almost all the teachers had heard about epilepsy, while a few of them knew someone with epilepsy or had seen a seizure. Some teachers, mainly from Group 1 , believed that either epilepsy was contagious or did not know the correct answer to this question.
Teachers in general did not discriminate or object to having epileptic children in their classes, although they recognized that there is a strong feeling of discrimination against epileptic people by the general population. Some teachers, mainly from Groups 1 
and 2, did not believe that a person with epilepsy could be as intelligent as other people, although most of them believed that someone who has epilepsy may become a good teacher. Almost half of all the teachers were misinformed about the initial procedures in attending a person during a seizure and also about its clinical characteristics.

Only 129 teachers (43\%) had any knowledge of the initial procedures during a seizure, presenting reasonable answers, although some incorrect ones were given and the main initial procedures as described in the methods were not refered to by many of them.

\section{DISCUSSION}

Studies like ours may sometimes be misinterpreted because of the particular methodology applied. Some of the questions are theoretical and individuals may answer in a "politically correct" manner, according to someone else's expectations and not reflecting their own opinions. Despite these limitations, this approach has been used in other reports ${ }^{12,13}$.

Teachers are usually in touch with epileptic children or adults. This requires a better educative program for these professionals in order to reduce the myths and fears surrounding epilepsy ${ }^{14}$. In our study, public school teachers predominated in Groups 1 and 3 , while those of private school were more prevalent in Group 2. This is probably the result of the educational structure of our region as most of the primary and tertiary level schools are public, while many of the secondary ones are private. Middle-age teachers were more prevalent in all groups and female teachers predominated in Group 1, reflecting a traditional tendency of our elementary schools. All the teachers had at least graduated from high school. Surprisingly, most of the teachers of Groups 1 and 2 had university qualifications. Not surprisingly, considering our country's educational problems and difficulties, most of the post graduated teachers were in Group 3.

In our study, most of the teachers had been familiarized with epilepsy as in other reports ${ }^{10,15,16}$, although many of them complained about their degree of information concerning this disease. In another study ${ }^{13}$ the majority had never been informed about epilepsy and this finding was related to the great number of equivocal answers obtained from them. The mythic idea of epilepsy as a contagious disease comes from the past. As in our work, others also reported this fact among teachers ${ }^{16}$ and it seems to be one of the most relevant problems observed. This idea was more prevalent in teachers from Group 1.
Nevertheless, some of them objected to having epileptic children in their classes, although most teachers did not. In another report, fifteen percent of the respondents preferred to place all children with epilepsy in a special classroom ${ }^{8}$. This preference may result from fear of handling the seizure of a student in the class. Most of the respondents did not report any kind of discrimination, although a few teachers did not think that an epileptic child might become a good teacher.

Unfortunately, many people still believe that epilepsy is a disease observed always in a mentally impaired person. In our study, some teachers had doubts about the cognitive potential of students with epilepsy mainly in Groups 1 and 2, which may reflect their inferior educational achievement and a consequent misinformation about this subject. Several teachers of all groups were misinformed about the clinical characteristics of the seizures, reflecting the lack of specific training. In fact, most people still believe that only the generalized tonic-clonic type is really a seizure.

We think this is one of the most misinformed aspects of epilepsy and it points to the necessity of educational clinical training. Still reflecting this reality, many of the teachers were not familiarized with the initial procedures in attending a person during a seizure. The initial procedures adopted by some teachers who answered this question would be somehow inappropriate, like to pull the tongue or to put objects in the subject's mouth, although the answers in general were not so far from the desired ones. Some of the wrong procedures were still related to mythical concepts. In another study, half of the respondents who had experience with first-aid management of seizures also used improper and potentially harmful measures ${ }^{8}$. These difficulties were probably related to poor educative programs in epilepsy. As the teachers are always in touch with epileptic children, school health services must be created in order to ensure that they should have sufficient knowledge about this disease ${ }^{10}$.

Physicians also play an important role as they have an understanding of seizures and medications that should be shared with teachers, who know what parts of students' learning seem to be affected by their epilepsy ${ }^{14}$. General public education campaign for epilepsy must also be encouraged in order to improve the quality of life of persons with epilepsy8. With increasing levels of formal education among the general population, especially in teachers, a more tolerant attitude towards epilepsy could be expected. 
Acknowledgements - The authors thank Prof. Francisco Antônio Morais de Souza for the statistical analysis orientation.

\section{REFERENCES}

1. Li S, Schoenberg BS, Wang C, Cheng X, Zhou S, Bolis CL. Epidemiology or epilepsy in urban areas of the People's Republic of China. Epilepsia 1985;26:391-394.

2. Tsuboi T. Prevalence and incidence of epilepsy in Tokyo. Epilepsia 1988;29:103-110

3. Gomez JG, Arciniegas E, Torres J. Prevalence or epilepsy in Bogota, Colombia. Neurology 1978;28:90-94.

4. Osuntokun BO, Adeuja AOG, Nottidge VA, et al. Prevalence of the epilepsies in Nigerian Africans: a community-based study. Epilepsia 1987;28:272-279.

5. Nicoletti A, Reggio A, Bartoloni A, et al. Prevalence of epilepsy in rural Bolivia: a door-to-door survey. Neurology 1999;53:2064-2069.

6. Mendizabal JE, Salguero LF. Prevalence of epilepsy in a rural community of Guatemala. Epilepsia 1996;37:373-376.

7. Viberg M, Blennow G, Polski B. Epilepsy in adolescence: implications for the development of personality. Epilepsia 1987; 28:542-546.
8. Kankirawatana P. Epilepsy awareness among schoolteachers in Thailand. Epilepsia, 1999; 40:497-501.

9. McLin WM, de Boer HM. Public perceptions about epilepsy. Epilepsia 1995; 36:957-959.

10. Bannon MJ, Wilding C, Jones PW. Teacher's perceptions of epilepsy. Arch Dis Child, 1992; 67:1467-1471.

11. Caveness WF, Gallup GH Jr. A survey of public attitudes toward epilepsy in 1979 with an indication of trends over the past thirty years. Epilepsia 1980; 21:509-518.

12. Santos IC, Guerreiro MM, Mata A, et al. Public awareness and attitudes toward epilepsy in different social segments in Brazil. Arq Neuropsiquiatr 1998; 56:32-38.

13. Tosetti MFV, Campos MA, Bauer CR, et al. Knowledge about epilepsy among teachers and epileptic patients. Arq Neuropsiquiat 1991;49:255259.

14. Marshall RM, Cupoli JM. Epilepsy and education: the pediatrician's expanding role. Adv Pediatr 1986;33:159-180

15. Gallhofer B. Epilepsy and its prejudice. Psychopathology 1984;17:187212.

16. Mielke J, Adamolekun B, Ball D, Mundanda T. Knowledge and attitudes of teachers towards epilepsy in Zimbabwe. Acta Neurol Scand 1997;96:133-137 